\title{
The Current Fish Fauna of Hopa Stream (Artvin, Turkey)
}

\author{
Davut TURAN ${ }^{1}$ Bülent VEREP ${ }^{2 *}$ \\ ${ }^{1}$ University of Recep Tayyip Erdoğan, Faculty of Fisheries, Departman of Basic Sciences of Fisheries, Inland Water Biology, \\ Campus of Zihni Derin, 53100, Rize, Türkiye. \\ ${ }^{* 2}$ University of Recep Tayyip Erdogan, Faculty of Fisheries. Departman of Basic Sciences of Fisheries, Marine Biology, Campus \\ of Zihni Derin, 53100, Rize; Türkiye.
}

How to cite: Turan, D. \& Verep, B. (2020). The Current Fish Fauna of Hopa Stream (Artvin, Turkey). J. Anatolian Env. and Anim. Sciences, 5(3), 378-381. Atıf yapmak için: Turan, D. \& Verep, B. (2020). Hopa Çayı'nın Güncel Balık Faunası (Artvin, Türkiye). Anadolu Çev. ve Hay. Dergisi, 5(3), $378-381$.

(iD): https://orcid.org/0000-0003-4238-8325 (iD) https://orcid.org/0000-0002-9586-6223

\section{*Corresponding author's:}

Bülent VEREP

University of Recep Tayyip Erdoğan, Faculty of Fisheries. Departman of Basic Sciences of Fisheries, Marine Biology, Campus of Zihni Derin, 53100, Rize; Türkiye.

\: bulent.verep@erdogan.edu.tr

Mobile telephone : +90 (533) 4536842

Telephone : +90 (464) 2233385

Fax : +90 (464) 2234118

\begin{abstract}
In the present study, the actual fish fauna of Hopa Stream was re-examined. The distribution and latest taxonomic status of the species were assessed. Overall, 3 sampling sites were investigated between 2005-2019 to reveal the inventory of fish species in the area. In total, 11 species were recognized. As a result of this study, one species of Gasterosteus aculeatus, which could not be detected in previous studies, were recorded for the first time. As a result, no significant differences were detected in the ecological balance of Hopa Stream in terms of fish fauna, since there is no loss of biodiversity from the previously reported species.
\end{abstract}

Keywords: Fish fauna, Hopa Stream, systematics, freshwater fish.

\section{Hopa Çayı'nın Güncel Balık Faunası (Artvin, Türkiye)}

*Sorumlu yazar:

Bülent VEREP

Recep Tayyip Erdoğan Üniversitesi, Su

Ürünleri Fakültesi. Su Ürünleri Temel Bilimleri

Bölümü, Deniz Biyolojisi, Zihni Derin

Kampüsü, 53100, Rize; Türkiye.

\: bulent.verep@erdogan.edu.tr

Mobile telephone : +90 (533) 4536842

Telephone : $+90(464) 2233385$

Fax $\quad:+90(464) 2234118$
Öz: Bu çalışmada, Hopa Çayınin balık faunası yeniden incelenmiştir. Türlerin dağıııımı ve son taksonomik durumları değerlendirilmiştir. Genel olarak, 2005-2019 yılları arasında bu akarsudaki balık türlerinin envanterinin çıkarılması için 3 örnekleme sahası öngörülmüş ve toplam 11 tür tespit edilmiştir. Yapılan bu çalışma sonucunda daha önceki çalışmalarda tespit edilemeyen Gasterosteus aculeatus türü ilk kez kaydedilmiştir. Daha önce belirlenen türlerden herhangi bir kaybın söz konusu olmaması sebebiyle Hopa Çayı'nın ekolojik dengesinde balık faunası açısından önemli değişiklik olmadığı söylenebilir.

\section{INTRODUCTION}

Abbolt, (1835) mentioned the existence of trout (Salmonidae) in fresh waters of Trabzon and Erzurum regions. Berg (1949), published a three-volume publications on fish living in the freshwater of Russia and neighboring countries. In his study, particular attention has been given to determine some freshwater fish species living in the streams and rivers of Black Sea region of Turkey. Slastenonko, (1955-1956) published a book containing both sea and freshwater fish living in the Black Sea Basin. In this book, it is mentioned that some fish species live in the streams and rivers in Trabzon, and Çoruh River. Aras (1974), conducted research on the biological 
and ecological characteristics of trout (Salmonidae) living in Çoruh and Aras Rivers. Kuru, (1975) reported 39 fish species and 29 subspecies belonging to 13 families as a result of systematic and zoogeographic examination of fish living in freshwater in the Tigris-Euphrates, Kura-Aras, Lake Van and the Central and Eastern Black Sea regions. Kutrup, (1994) investigated the fish living in freshwaters of Trabzon in terms of taxonomic and ecological aspects. Turan, (2003) studied freshwater fish in Rize and Artvin regions in terms of taxonomic and ecological properties. Turan et al., (2005) reported 7 species and 2 subspecies belonging to 4 families from Hopa Stream. Freyhof et al., (2018) recorded Cobitis satunini from Hopa Stream. In this study, the current status of extant fish species in Hopa Stream has been discussed.

\section{MATERIAL AND METHOD}

The study area comprises the Hopa Stream. The Hopa Stream is about $30 \mathrm{~km}$ length and originate from Cankurtaran mountain. Overall, 3 sampling sites (upper, middle and lower), were detected to reveal fishes in the area. No environmental problems were observed in this stream during fish sampling (define the sampling period e.g. between 2018 and 2019). The physico-chemical properties of water of Hopa Stream are as follows as temperature $16.4{ }^{\circ} \mathrm{C}$; $\mathrm{pH} 7.5$; electrical conductivity 138.8 $\mu \mathrm{S} / \mathrm{cm}$; dissolved oxygen $10.0 \mathrm{mg} / \mathrm{L}$, suspended material $18.3 \mathrm{mg} / \mathrm{L}$; nitrite $0.16 \mathrm{mg} / \mathrm{L}$; nitrate $0.4 \mathrm{mg} / \mathrm{L}$; sulfate 7.33 $\mathrm{mg} / \mathrm{L}$ and orto-phosphate $0.7 \mathrm{mg} / \mathrm{L}$ (Mutlu, 2019). Fishes were caught between 2004-2018 by Samus 1000 pulsed DC electro-fishing equipment, cast nets and gillnets from 3 sampling sites. After anesthesia, fish specimens were fixed in $4 \%$ formaldehyde and transferred to the laboratory for further identification. Formalin-fixed specimens were deposited at FFR (Recep Tayyip Erdogan University Zoology Museum of the Faculty of Fisheries, Rize). We followed by Baycelebi et al., $(2015,2017)$ to identify species. Common and local names of the species originate from FishBase (Froese and Pauly, 2019).

\section{RESULTS}

Overall, 11 fish species (Table 1) belonging to seven families were recognized. The most species-rich family in the area is Leuciscidae (4 species), followed by Mugilidae (2), Salmonidae (1), Cyprinidae (1), Cobitidae (1), Gobiidae (1) and Gasteriostedae (1).

Family: Salmonidae

Salmo rizeensis Turan, Kottelat \& Engin, 2010 (Figure 1)

Type locality: Çoruh River

Turkish name: Dağ alası
English name: Mountain trout

Distributed area: Upper part of Hopa Stream.

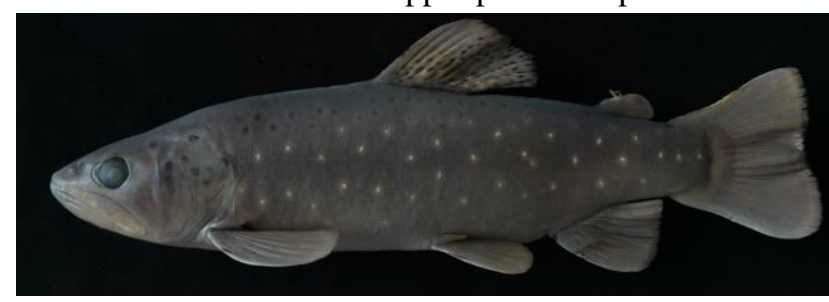

Figure 1. Mountain trout (Salmo rizeensis)

Family: Cyprinidae

Barbus tauricus (Steindachner, 1897) (Fig. 2)

Type locality: Kırım

Turkish name: Bıyıklı balık

English name: Crimean barbel

Distributed area: Middle part of Hopa Stream

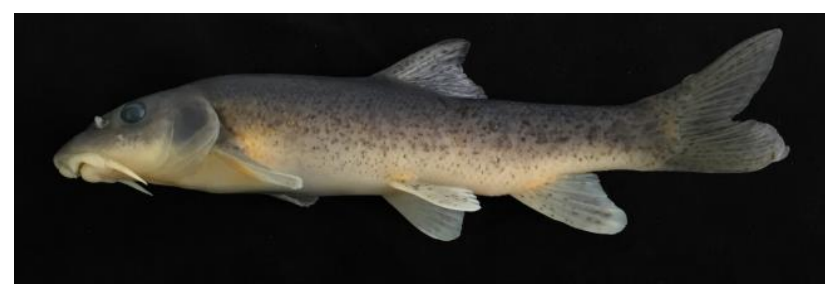

Figure 2. Crimean barbel (Barbus tauricus)

Family: Leuciscidae

Alburnoides fasciatus (Nordman, 1840) (Fig. 3)

Type locality: Steams of Eastern Black Sea region Turkish name: Noktalı inci balığ 1

English name: Spirlin

Distributed area: Middle part of Hopa Stream

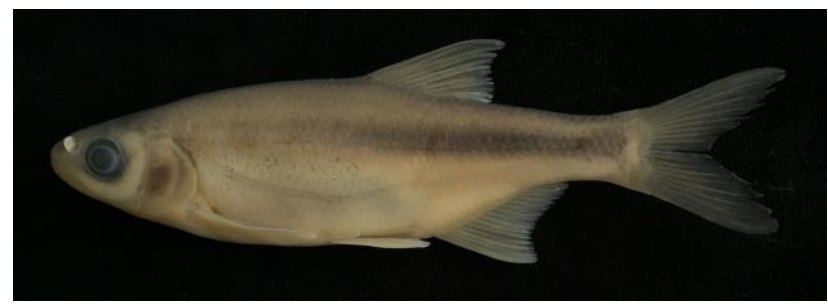

Figure 3. Spirlin (Alburnoides fasciatus)

Alburnus derjugini Berg, 1923 (Fig. 4)

Type locality: Batumi (Georgia)

Turkish name: İnci balığ

English name: Georgian shemaya

Distributed area: Middle part of Hopa Stream

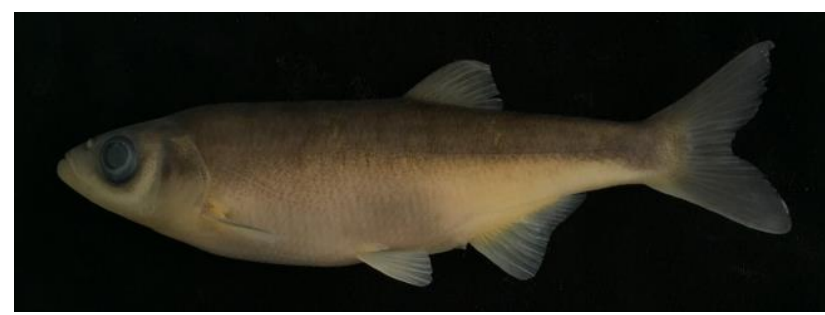

Figure 4. Georgian shemaya (Alburnus derjugini ) 
Rutilus frisii (Nordmann, 1840) (Fig. 5)

Type locality: Volga River (Russia)

Turkish name: Kutum, Levkit balığ

English name: Black Sea roach

Distributed area: Lower part of Hopa Stream

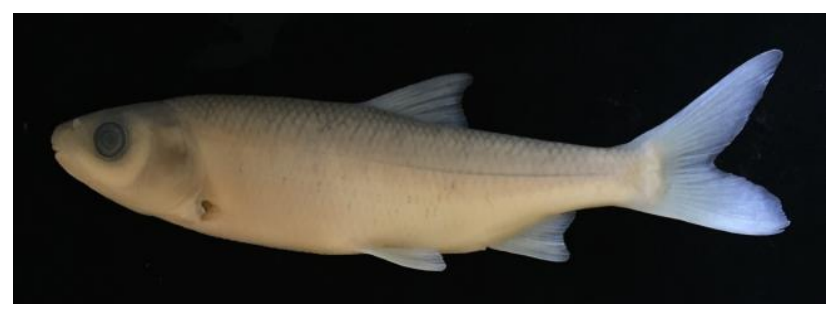

Figure 5. Blacksea roach (Rutilus frisii).

Squalius cf seyhanensis (Fig. 6)

Turkish name: Tatlısu kefali

English name: Chub

Distributed area: Lower and middle part of Hopa Stream.

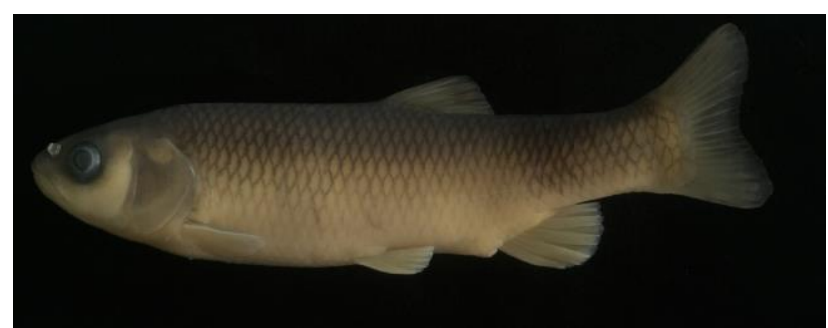

Figure 6. Chub (Squalius cf seyhanensis)

\section{Family: Cobitidae}

Cobitis satunini Glabkov, 1935 (Fig. 7)

Type locality: Small streams draining into Black Sea

Turkish name: Taşyiyen balık

English name: Splendid spined loach

Distributed area: Lower part of Hopa Stream

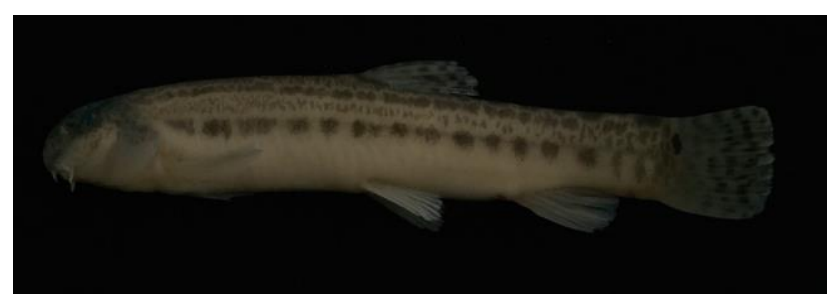

Figure 7. Splendid spined loach (Cobitis satunini)

\section{Family Mugilidae}

Mugil cephalus Linnaeus, 1758 (Fig. 8)

Type locality: European Sea

Turkish name: Avrita balı̆̆ı, has kefal,, topan balığı, topbaş balığı

English name: Flathead grey mullet

Distributed area: Lower part of Hopa Stream

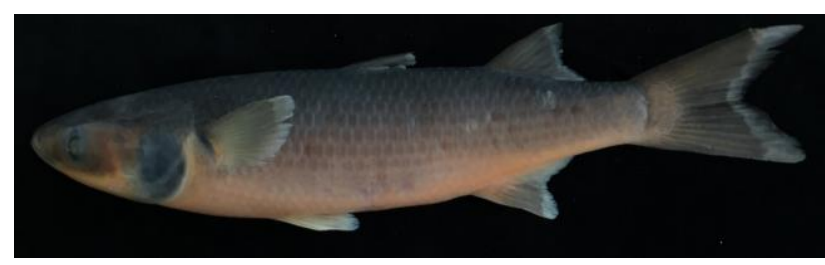

Figure 8. Flathead grey mullet (Flathead grey mullet).

Chelon aurata (Risso, 1810) (Fig.9)

Type locality: Nice (France)

Turkish name: Altınbaş kefal balığı

English name: Golden grey mullet

Distributed area: Lower part of Hopa Stream

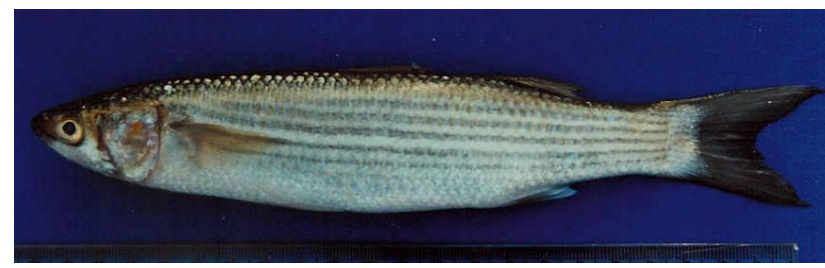

Figure 9. Golden grey mullet (Chelon aurata)

\section{Family Gobiidae}

Ponticola constructor (Nordmann, 1840) (Fig. 10)

Type locality: Çoruh River

Turkish name: Kaya balı̆̆

English name: Caucasian goby

Distributed area: Lower part of Hopa Stream

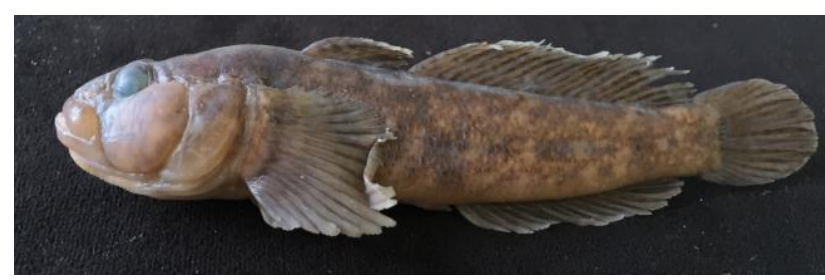

Figure 10. Caucasian goby (Ponticola constructor).

\section{Family: Gasteriostedae}

Gasterosteus aculeatus Linnaeus, 1758 (Fig. 11)

Type locality: Europe

Turkish name: Dikence valığ 1

English name: Three-spined stickleback

Distributed area: Lower part of Hopa Stream

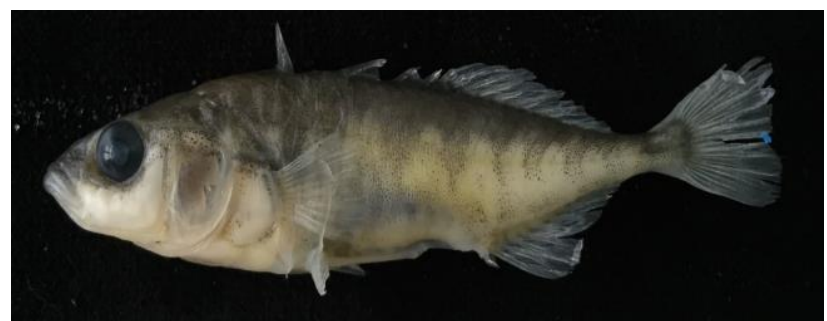

Figure 11. Three-spined stickleback (Gasterosteus aculeatus). 


\section{DISCUSSION}

As a result of this study, 11 fish species currently distributes in Hopa Stream were identified. In previous study conducted by Turan, (2004), 7 species and 2 subspecies were recorded in the stream. Most of these species do not reflect current fish fauna. In this study, the current names of the species are given (Table 1). Additionally, Gasterosteus aculeatus have been recorded for the second time in the streams and river in eastern Turkish cost of Black Sea after the last thirty years. The freshwater chub species distributed in the Hopa stream is genetically similar to Squalius seyhanensis. Therefore, we identified it as Squalius $c f$. seyhanensis.

Table 1. Comparison of the results of this study with Turan et al., (2005).

\begin{tabular}{ll}
\hline Turan et al., (2005) & This study \\
\hline Salmo trutta labrax & Salmo rizeensis \\
Neogobius kessleri & Ponticola constructor \\
Leuciscus cephalus & Squalius cf. seyhanensis \\
Alburnoides bipunctatus & Alburnoides fasciatus \\
Barbus tauricus escherichi & Barbus tauricus \\
Rutilus frisii & Rutilus frisii \\
Chalcalburnus chalcoides & Alburnu derjugini \\
Liza aurata & Chelon auratus \\
Mugil cephalus & Mugil cephalus \\
- & Cobitis satunini \\
- & Gasterosteus aculeatus \\
\hline
\end{tabular}

\section{ACKNOWLEDGEMENTS}

We would like to thank Esra Bayçelebi (Rize) and Cüneyt Kaya (Rize) for their help during the fieldwork. We also thank Münevver Oral for proofreading the manuscript.

\section{REFERENCES}

Aras, S. (1974). Çoruh ve Aras Havzası Balıkları Üzerinde Biyo-Ekolojik Araştırmalar. Doktora Tezi, Atatürk Üniversitesi Ziraat Fakültesi Zootekni Bölümü, Erzurum, 82s.

Baycelebi, E., Turan, D. \& Japoshvili, B. (2015). Fish fauna of Çoruh river and two first record for Turkey. Turkish Journal of Fisheries and Aquatic Sciences, 15, 783-794.

Baycelebi, E., Kaya, C. \& Turan, D. (2017). Rize İli’nin güncel balık faunası. Journal of Anatolian Environmental and Animal Sciences, 2(2) 43-46.

Berg, L.S. 1948-49. [Freshwater fishes of the U.S.S.R. and adjacent countries]. Izdatelstvo Akademii Nauk SSSR, Moskva \& Leningrad, vol. 1 (1948), vols. 2-3 (1949). [In Russian; translation: Israel Program for Scientific Translations, Jerusalem, 1965].

Kuru, M. (1975). Dicle-Fırat, Kura-Aras, Van Gölü Karadeniz Havzası Tatlisularında Yaşayan Balıkların (Pisces) Sistematik ve Zoocoğrafik
Yönden Incelenmesi. Doçentlik Tezi, Atatürk Üniversitesi, Fen Fakültesi, Erzurum, 180s.

Kutrup, B. (1994). Trabzon Yöresindeki Tatlisu Balıklarının Taksonomisi ve Ekolojik Özellikleri Üzerine Araştırmalar. Doktora Tezi, K.T.Ü. Fen Bilimleri Enstitüsü, Trabzon, 64s.

Mutlu, T. (2019). Doğu Karadeniz Havzasında Bazı Akarsuların Eser Element Düzeyleri ve Karadeniz'e Girdilerinin Durayl Karbon ve Azot İzotop Oranlarlyla Belirlenmesi. Doktora Tezi, RTEÜ Fen Bilimleri Enstitüsü, Su Ürünleri Ana Bilim Dal1, Rize, $118 \mathrm{~s}$.

Turan, D. (2003). Rize ve Artvin Yöresindeki Tatlisu Balıklarının Sistematik ve Ekolojik Yönden Incelenmesi. Doktora Tezi, Ege Üniversitesi, Fen Bilimleri Enstitüsü, İzmir, 182s

Turan, D., Verep, B., Şahin, C. \& İmamoğlu, H.O. (2015). Hopa Çayı'nda yaşayan balıklar üzerine taksonomik bir araştırma. Türk Sucul Yaşam Dergisi, 3(2), 96-99.

Turan, D., Kottelat, M. \& Engin, S. (2010). Two new species of trouts, resident and migratory, sympatric in streams of northern Anatolia (Salmoniformes: Salmonidae). Ichthyological Exploration of Freshwaters, 20(4), 333-364. 